\title{
Chapter 38 \\ Article 38: The Right to Protection from Armed Conflict
}

\author{
Gerison Lansdown
}

1. States Parties undertake to respect and to ensure respect for rules of international humanitarian law applicable to them in armed conflicts which are relevant to the child.

2. States Parties shall take all feasible measures to ensure that persons who have not attained the age of 15 years do not take a direct part in hostilities.

3. States Parties shall refrain from recruiting any person who has not attained the age of 15 years into their armed forces. In recruiting among those persons who have attained the age of 15 years but who have not attained the age of 18 years, States Parties shall endeavour to give priority to those who are oldest.

4. In accordance with their obligations under international humanitarian law to protect the civilian population in armed conflicts, States Parties shall take all feasible measures to ensure protection and care of children who are affected by an armed conflict.

\section{What Did Children Say?}

'Children have to be educated on the dangers of armed conflict. A law has to be there that would protect children from participating in armed conflict.' (Africa).

(continued)

G. Lansdown ( $\square)$

Carleton University, Ottawa, ON, Canada 
Children should never be forced to fight in the armed or militia forces, go to war or engaged in any conflict. (Africa).

Useful activities to engage children with rather than having free time to engage in those military parties. (Asia-Pacific).

Awareness workshops for children against recruitment to the armed conflicts and to be a child soldier. (Asia-Pacific).

\section{Overview}

Article 38 introduces a framework for the protection of children in situations of armed conflict, both as civilians and as combatants or recruits to state armed forces or non-state armed groups. When drafted, it was unique in introducing international humanitarian law into a human rights treaty, thus affording it universal application, rather than being applicable only in times of armed conflict (Ang, 2005, p. 10). During the drafting process, Article 38 was probably the most contentious of all the Convention provisions, with strongly divided opinions on the proposed minimum age of recruitment into armed forces, differentiation between recruitment into state and non-state forces, age and level of protection from participation in conflicts, and the extent of measures demanded of States Parties in providing protection (Office of the United Nations High Commissioner for Human Rights and Rädda barnen (Society: Sweden), 2007, pp. 775-799). Disagreement arose as to whether the Working Group charged with drafting the text of the Convention had the mandate to review existing standards for protection in international humanitarian law, while fears were also expressed that the text might undermine or weaken those existing standards (Office of the United Nations High Commissioner for Human Rights and Rädda barnen (Society: Sweden), 2007, p. 794). Faced with the risk of no provision at all, the result was a compromise text affording much lower levels of protection than many members of the Working Group were seeking. In response, the Optional Protocol on children in armed conflict was later developed to strengthen the standards, although it, too, falls short of the protections sought by many working in this field. In response, the Paris Principles, published by UNICEF in 2007, affirm that most child protection actors will continue to press for the raising of the age of recruitment or use of children to 18 years in all cases (UNICEF, 2007).

In summary, Article 38 requires of States Parties that they ensure compliance with international humanitarian law, protect children under the age of 15 from direct participation in hostilities, refrain from recruiting children under 15 into armed forces, and take measures to protect civilian children affected by armed conflict. The Optional Protocol on armed conflict strengthens these provisions by raising the voluntary recruitment age to 16 years, and encouraging further raising of that age, prohibiting compulsory recruitment under 18 years, as well as any recruitment under 18 years by armed groups, and imposing obligations on States Parties to ensure that children under 18 do not directly participate in hostilities (UN General Assembly, 
2001, paras. 1-4). It is important to note that the Committee highlights the complexity of addressing children's rights in situations of conflict and insists that States Parties have obligations to take measures to secure all the rights of children within their jurisdiction during such times, with no differentiation between child civilians or combatants, thus affirming the human rights principle of universality (Ang, 2005, p. 29; UN Committee on the Rights of the Child, 1992, para. 62 (d)). ${ }^{1}$ Furthermore, the Convention is not subject to derogation in time of public emergency (Ang, 2005, p. 59; Hodgkin et al., 2007, p. 573; UN Committee on the Rights of the Child, 1992, para. 67).

\section{General Principles}

Article 2 All children suffer from exposure to armed conflict, but the Committee has highlighted the vulnerability of girls to systemic and serious sexual violence and sexual slavery in this context and urges States Parties to take measures to address the specific needs of formerly recruited girls in programmes of recovery and reintegration. ${ }^{2}$ In this regard, no differentiation must be made between children who have been recruited or used and those who have not (UNICEF, 2007, para. 3.3). Discrimination and exclusion also result in children with disabilities being disproportionately vulnerable to violence, exploitation, and sexual abuse (UN High Commissioner for Refugees, 2003). The severity of the problems faced by children with disabilities led to the development of guidelines by the UNHCR to highlight the risks, strengthen protection and encourage States Parties to provide appropriate support (UN Executive Committee of the UNHCR Programme, 2010, Chap. III A).

Article 3 All measures to protect children from participation in or exposure to the consequences of armed conflict are premised on the recognition that so doing is in their best interests and must be determined by those best interests (UNICEF, 2007, para. 3.4).

Article 6 Children's exposure to armed conflict either as a civilian or combatant intensifies risk to optimum development, as well as loss of life. It potentially places at risk the realisation of all rights. Article 38 and the OPAC are drafted, although arguably inadequately, to seek to provide the maximum possible protection to enable children to live and thrive even in situations of armed conflict. Programmes and policies intended to benefit children associated with armed forces or armed groups should be informed by a child development perspective. Furthermore, in accordance with Article 37, capital punishment or imprisonment for life without possibility of release shall never be used against any person who is proved to have committed an

\footnotetext{
${ }^{1}$ See also, for example, Concluding observations: Cambodia (2000a, para. 48).

${ }^{2}$ See, for example, concluding observations for Colombia, (2015, para. 65) and Democratic Republic of Congo (2017a, para. 48).
} 
offence against international or domestic criminal law while under 18 years of age (UNICEF, 2007, para. 3.9, 3.10).

Article 12 The Committee has consistently recommended that children must be involved in the development of all legislation, policies, and programmes that affect them (2009, para. 27, 2016a, para. 23). It has stressed the imperative to involve children in peace movements, programmes of non-violent conflict resolution, resilience building, and peace processes (2015, para. 65, 2016a, para. 82).

\section{Articles Related or Linked to Article 38}

Article 7, as children who are not registered at birth or subsequently are more vulnerable to underage recruitment into state armed forces or armed groups.

Article 8, as children caught up in armed conflict are at risk of loss of identity through loss of relevant papers.

Article 10 provides for the right to reunification in context of separation from families during or following armed conflict.

Article 11, as armed conflict can increase the risk of illicit transfer of children.

Article 13, since rights to freedom of expression may be curtailed in situations of armed conflict.

Article 15, as the right to peaceful of assembly may be curtailed in situations of armed conflict.

Article 19, as children affected and/or involved in armed conflicts are more at risk of experiencing neglect, violence, and abuse.

Article 22 applies as children may need to seek refugee status in situations of conflict.

Article 23, since armed conflict both places children at risk of experiencing disabling injuries and those who have a disability are at greater risk.

Article 24, as the right to health is potentially jeopardised in situations of conflict.

Article 28, since protecting the right to education needs to be prioritised in situations of armed conflict.

Article 29, since preparation for life in spirit of peace takes on added significance in both mitigating risk of conflict and promoting peace post-conflict.

Article 31, as exercising the right to play and leisure affords children opportunities to escape and heal in the context of the traumatic experiences of armed conflict.

Article 32, as forcible recruitment into armed forces or groups constitutes a prohibited form of worst child labour.

Article 34, since children, especially girls, can be exposed to sexual violence and exploitation in situations of armed conflict, both as civilians and as conscripts into armed forces or groups.

Article 35, since, in armed conflict, children are more at risk to be abducted, trafficked, or sold for various purposes including recruitment into armed groups. 
Article 36, as armed conflict renders children vulnerable to all forms of exploitation.

Article 37, as children can be subjected to torture, and other forms of cruel, inhuman and degrading treatment in situations of conflict, both as civilians and as conscripts into armed forces or groups.

Article 39, as children must be provided with opportunities to achieve physical and psychological recovery and reintegration, both after release from recruitment into armed forces and direct experience of conflict as a civilian.

Article 40, since there is no consensus at the international level as to the appropriate minimum age for prosecution of child soldiers.

Optional Protocol to the Convention on the Rights of the Child on the involvement of children in armed conflict (OPAC), 2000

\section{Relevant Instruments}

A significant number of instruments contribute to the body of international and regional humanitarian and human rights law, and impact on the rights of children in the context of armed conflict. The following are the most relevant.

UN Declaration of the Rights of the Child (1959) Principle 8.

International Covenant on Civil and Political Rights (1966), Article 24.

UN Declaration on the Protection of Women and Children in Emergency and Armed Conflict (1974).

UN Convention on the Prohibition of the Use, Stockpiling, Production and Transfer of Anti-Personnel Mines and on their Destruction (Ottawa Convention or the Anti-Personnel Mine Ban Treaty) (1997).

UNICEF Principles and guidelines on children associated with armed forces or armed groups (Paris principles) (2007).

The Geneva Convention for the amelioration of the condition of the wounded and sick in armed forces in the field (1949), the Fourth Convention, the later (1977) Additional Protocol One to Geneva Conventions, dealing with international conflicts and in particular Article 77 and 78 that introduce specific protection to children, and the later (1977) Additional Protocol Two to the Geneva convention, dealing with non-international conflicts, and in particular Article 4 on special measures for children.

ILO Convention 182, Worst Forms of Child Labour (1999), forced recruitment of children is defined as a worst form of child labour.

African Charter on the Rights and Welfare of the Child (1990), Article 22 establishes age 18 as minimum for all compulsory recruitment and participation in hostilities.

Rome Statute of International Criminal Court (1998) establishes as war crimes: enlistment and use of persons under age 15 a war crime, attacks on schools and hospitals, rape and other forms of violence against children. 


\section{Attributes}

\section{Attribute One: Respect for International Humanitarian Law Applicable to the Child}

It is important to note that humanitarian law, which comprises Hague law, dealing broadly with use of weapons, and Geneva law that serves to protect those affected by conflict, only applies during the period of an armed conflict. ${ }^{3}$ Furthermore, the Geneva Conventions and protocols only extend protection to those who do not take part in hostilities and therefore provide no protection for children recruited or used as combatants. It therefore contrasts, and is, to some extent, in tension with Article 38, paragraph 1 (and indeed, the Convention in its entirety), which applies to all children under 18 years, consistent with Article 1, whether civilian or combatants. This is a complex arena of law, but the Committee has sought to address it, by arguing that Article 41 of the Convention asserts that States Parties must always apply the norms most conducive to the rights of the child, whether in applicable international law or national legislation (1992, para. 75 (e)). ${ }^{4}$

Article 38 applies to both internal and external conflicts. It requires States Parties to both respect and ensure respect for international humanitarian law applicable to children and provides the framework for effective monitoring of compliance with Article 38, together with relevant provisions of international humanitarian law. Paragraph 1 imposes an obligation on States Parties to respect the law, including in contexts where other parties to a conflict are not signatories to it (Kupreškić et al. (IT-95-16), 2000), and the obligation to ensure respect includes the regulation of behaviour of non-state actors such as armed groups, or rebel forces (de Detrick, 1999, p. 651). The Committee has also argued that the obligation extends to paramilitary groups and private companies (2001a, para. 6, 2004a, para. 71 (d)). Together they have been interpreted to require establishment of minimum ages for recruitment, dissemination of information on humanitarian law, provision of training programmes on the rights of the child, and implementation of penal obligations under international humanitarian law for breaches of the Geneva Conventions (1998, para. 14, 2017b, para. 67). The Committee has given a high priority to challenging impunity, recommending establishment of judicial mechanisms to deal with gross violations, and making sanctions widely known (2000b, para. 45). It has also called for States Parties to amend their penal law in order to provide for the exercise of extraterritorial jurisdiction for the offences committed by or against a citizen of the States Party (2010, para. 26). In its guidelines for OPAC, the Committee seeks detailed information on sanctions in force, their scope and the extent of their

\footnotetext{
${ }^{3}$ See 'The Geneva Conventions of 1949 and their Additional Protocols' (International Committee of the Red Cross, 2010).

${ }^{4}$ See also 'The Rights of Children in Armed Conflict' (Tobin \& Drumbl, 2019, pp. 1511-1514) for a fuller discussion of the relationship between international humanitarian law and human rights law.
} 
application and implementation (2007a, paras. 20-26). It also calls for states to become parties to all relevant instruments (2007a, para. 22).

\section{Attribute Two: Age Limits on Participation in Hostilities}

Article 38 must be applied with regard to international humanitarian law, as well as the provisions of OPAC. However, the protected age for participation in hostilities and the nature and scope of protection varies significantly in the different instruments.

Article 38 paragraph 2 introduces 15 years as the minimum age for direct participation in hostilities. This is amended by OPAC which demands 'all feasible measures' to ensure that children under age 18 in the armed forces do not take a direct part in hostilities but provides stronger protection in respect of armed groups which are prohibited from allowing any participation of children under 18 years. 'All feasible measures' is a weak requirement that does not appear elsewhere in international human rights language and there is no clear definition of its meaning. However, despite the limitations of Article 38 and OPAC, the Committee has consistently pressed States Parties to employ 18 years as the minimum age for any participation in hostilities (2017a, para. 48). Their focus is on determining outcomes (whether any actual participation has taken place) rather than processes (what feasible measures have been adopted to preclude participation of persons under age 18).

Further complexities arise in respect of defining direct participation in hostilities. There is consistency in the interpretation of the concept of hostilities, which are commonly understood to describe acts of war intended to hit personnel and facilities of an opposing armed force, including preparations for and return from combat (International Committee of the Red Cross, 1987). In addition, a consensus exists that any participation is understood to be judged objectively and not in relation to the will or choice of the child in question (Ang, 2005, p. 36). However, the definition of 'direct participation' in hostilities is less clear. A higher standard applies in the Additional Protocols, which prohibit any participation by children in hostilities. The associated commentaries make clear that the intention was to keep all children away from all hostilities in every way (Ang, 2005, p. 38). The International Criminal Court appears to limit the definition to actual fighting, which narrows the scope and thereby allows for a far wider range of permitted activities on the part of children. Many types of indirect participation can expose children to significant risk, for example, engagement as messengers, spies, or porters. Again, the position of the Committee has been unambiguous, as it presses States Parties to ensure neither direct or indirect participation of any children under 18 years, and welcomes commitments from States Parties to adopt such policies (2004b, paras. 81-82, 2005a, paras. 69-70, 2005b, para. 82, 2005c, paras. 65-66). 


\section{Attribute Three: Age of Recruitment}

As noted above, different standards prevail in different relevant instruments regarding age of recruitment. Article 38 prohibits recruitment of children under the age of 15 years and this prohibition applies to compulsory, forced, and voluntary recruitment (Ang, 2005, p. 50). Under International Labour Organization 182 and OPAC, compulsory or forced recruitment under age 18 is prohibited, and OPAC requires States Parties to raise the minimum age for voluntary recruitment to 16 years, and further urges States Parties to raise it to 18 years, taking into account that the Convention affords special protection for all children (UN General Assembly, 2001, Annex I, Article 3, para 1). It also prohibits any recruitment of persons under 18 by armed groups.

In respect of recruiting children aged between 15 and 18 years, Article 38 requires States Parties to endeavour to give priority to those who are oldest. This relatively weak formulation imposes an obligation merely of conduct, not of result. However, the commentaries to the Additional Protocols argue that the concept of 'endeavour' points to a duty, which can be extended by implication to the implementation of Article 38, to establish a system guaranteeing the obligation to apply the priority rule (Ang, 2005, p. 57). In any case, the Committee has made clear that it seeks an end to all recruitment of persons under 18 years old in all contexts, and consistently presses States Parties to take measures to achieve that objective (1992, para. 61 et seq, 2016b, para. 85, 2017a, para. 48, 2017c, para. 9). It also presses States Parties to take measures to de-mobilise children already recruited and to facilitate their recovery and reintegration (2017d, para. 38).

\section{Attribute Four: All Feasible Measures of Care and Protection}

Article 38, paragraph 4, requires States Parties to take all feasible measures to ensure protection and care for civilian children in accordance with obligations under international humanitarian law. Notably child combatants are excluded. General protection measures elaborated in international humanitarian law, such as the Geneva Conventions and their Additional Protocols, require humane treatment, including respect for life and physical and moral integrity, and they forbid coercion, corporal punishments, torture, collective penalties, and reprisals. Additional specific protections are afforded to children including, for example, the right to care and aid, family unity, special care for orphans or separated children, education, special treatment for children deprived of their liberty, and a prohibition on the death penalty. These provisions represent a considerable overlap with rights embodied in the Convention and the approach of the Committee is to identify violations in terms of all the applicable Convention articles, including the right to education. In relation to Article 38 paragraph 4, the Committee asserts education to be a core obligation in situations of emergency in light of its significance as a measure of physical, 
psychological, and cognitive protection (2008, para. 29), and also regularly raises States Parties' compliance with the Ottawa Convention on Landmines, urging action on de-mining, prevention, and rehabilitation for victims, as well as advocating ratification (2006, para. 69, 2007b, paras. 23, 78).

The formulation of 'all feasible measures' represents a considerable weakening of the provisions in the Geneva Conventions and Additional Protocols, which employ unambiguous language such as 'shall take all necessary steps' (Ang, 2005, p. 62). The Committee has taken a clear position on this, consistently employing stronger terms with which to press States Parties into action and demanding more than the strict letter of Article 38, paragraph 4, would indicate. For example, a formulation has been used stating that States Parties should 'at all times ensure respect for human rights and humanitarian law aimed at the protection and care of children in armed conflict' (UN Committee on the Rights of the Child, 2000c, para. 49, 2000d, para. 64, 2001b, para. 57 (a)).

With regards to the rights of children who are alleged to have committed offences, Articles 37 and 40, taken together with the United Nations rules and guidelines on juvenile justice and the Committee's General Comments no. 6 and no. 10, make clear that, although such children may be held accountable for crimes, any hearings to determine responsibility must be fair and entirely separate from the adult justice system and that the subsequent treatment of the child must be focused on achieving their rehabilitation, with deprivation of liberty used only as a last resort for the shortest appropriate time.

\section{References}

Ang, F. (2005). A Commentary on the United Nations Convention on the Rights of the Child, Article 38: Children in Armed Conflicts. A Commentary on the United Nations Convention on the Rights of the Child, Article 38: Children in Armed Conflicts. Brill Nijhoff. Retrieved November 29, 2020, from https://brill.com/view/title/11620

de Detrick, S. L. (1999). A Commentary on the United Nations Convention on the Rights of the Child. Brill Nijhoff. Retrieved November 6, 2020, from https://brill.com/view/title/10630

Hodgkin, R., Newell, P., \& UNICEF. (2007). Implementation handbook for the convention on the rights of the child (3rd ed.). : UNICEF. Retrieved September 21, 2020, from https:// digitallibrary.un.org/record/620060? $1 n=e n$

International Committee of the Red Cross. (1987). Commentary on the Additional Protocols of 8 June 1977 to the Geneva Conventions of 12 August 1949. International Committee of the Red Cross. Retrieved November 29, 2020, from https://www.icrc.org/en/publication/0421commentary-additional-protocols-8-june-1977-geneva-conventions-12-august-1949

International Committee of the Red Cross. (2010, October 29). The Geneva conventions of 1949 and their additional protocols. International Committee of the Red Cross. Retrieved November 29, 2020, from https://www.icrc.org/en/war-and-law/treaties-customary-law/genevaconventions

Kupreškić, M., et al. (2000). (IT-95-16) (International Criminal Tribunal for the former Yugoslavia (ICTY) 14 January 2000). Retrieved November 29, 2020, from https://www.icty.org/case/ kupreskic 
Office of the United Nations High Commissioner for Human Rights \& Rädda barnen (Society: Sweden). (2007). Legislative history of the convention on the rights of the child. New York: United Nations. Retrieved from https://digitallibrary.un.org/record/602462? $1 \mathrm{n}=\mathrm{en}$

Tobin, J., \& Drumbl, M. A. (2019). Article 38: The rights of children in armed conflict. In J. Tobin (Ed.), The UN convention on the rights of the child: A commentary (pp. 1503-1560). Oxford University Press.

UN Committee on the Rights of the Child. (1992). Report adopted by the Committee at its 46th Meeting on 9 October 1992, CRC/C/10. UN. Retrieved November 29, 2020, from http:// digitallibrary.un.org/record/197134

UN Committee on the Rights of the Child. (1998). Concluding observations: Iraq, October 26, 1998, CRC/C/15/Add.94. UN. Retrieved November 29, 2020, from http://digitallibrary.un. org/record/265317

UN Committee on the Rights of the Child. (2000a). Concluding observations: Cambodia, June 28, 2000, CRC/C/15/Add.128. UN. Retrieved November 29, 2020, from http://digitallibrary.un. org/record/424986

UN Committee on the Rights of the Child. (2000b). Concluding observations: Sierra Leone, February 24, 2000, CRC/C/15/Add.116. UN. Retrieved November 29, 2020, from http:// digitallibrary.un.org/record/414185

UN Committee on the Rights of the Child. (2000c). Concluding observations: Armenia, February 24, 2000, CRC/C/15/Add.119. UN. Retrieved November 7, 2020, from http://digitallibrary.un. org/record/415621

UN Committee on the Rights of the Child. (2000d). Concluding observations: India, February 23, 2000, CRC/C/15/Add.115. Retrieved October 11, 2020, from https://digitallibrary.un.org/ record $/ 412551 ? \mathrm{ln}=\mathrm{en}$

UN Committee on the Rights of the Child. (2001a). Concluding observations: Democratic Republic of the Congo, July 9, 2001, CRC/C/15/Add.153. UN. Retrieved November 29, 2020, from http:// digitallibrary.un.org/record/451937

UN Committee on the Rights of the Child. (2001b). Concluding observations: Bhutan, July 9, 2001, CRC/C/15/Add.157. UN. Retrieved November 29, 2020, from http://digitallibrary.un.org/ record/451942

UN Committee on the Rights of the Child. (2004a). Concluding observations: Indonesia, February 26, 2004, CRC/C/15/Add.223. UN. Retrieved November 29, 2020, from http://digitallibrary.un. org/record $/ 530584$

UN Committee on the Rights of the Child. (2004b). Concluding observations: Myanmar, June 30, 2004, CRC/C/15/Add.237. UN. Retrieved Occtober 26, 2020, from http://digitallibrary.un. org/record $/ 536569$

UN Committee on the Rights of the Child. (2005a). Concluding observations: Algeria, October 12, 2005, CRC/C/15/Add.269. Retrieved October 24, 2020, from https://digitallibrary.un.org/ record $/ 570473 ? \mathrm{ln}=\mathrm{en}$

UN Committee on the Rights of the Child. (2005b). Concluding observations: Nepal, September 1, 2005, CRC/C/15/Add.261. Retrieved Octobber 11, 2020, from https://digitallibrary.un.org/ record $/ 569886 ? \mathrm{ln}=\mathrm{en}$

UN Committee on the Rights of the Child. (2005c). Concluding observations: Uganda, November 23, 2005, CRC/C/UGA/CO/2. UN. Retrieved November 6, 2020, from http://digitallibrary.un. $\mathrm{org} / \mathrm{record} / 570558$

UN Committee on the Rights of the Child. (2006). Concluding observations: Lebanon, June 8, 2006, CRC/C/LBN/CO/3. Retrieved October 11, 2020, from https://digitallibrary.un.org/ record $/ 580379 ? \mathrm{ln}=\mathrm{en}$

UN Committee on the Rights of the Child. (2007a). Revised guidelines regarding initial reports to be submitted by States Parties under Article 8, para. 1, of the Optional Protocol to the Convention on the Rights of the Child on Involvement of Children in Armed Conflict, September 2007, CRC/C/OPAC/2. UN. Retrieved November 29, 2020, from http://digitallibrary.un.org/ record/635885 
UN Committee on the Rights of the Child. (2007b). General Comment No. 9 (2006) The rights of children with disabilities, November 13, 2007, CRC/C/GC/9. Retrieved October 12, 2020, from https://digitallibrary.un.org/record/593891? $\mathrm{ln}=\mathrm{en}$

UN Committee on the Rights of the Child. (2008). Day of general discussion: The right of the child to education in emergency situations. UN. Retrieved December 20, 2020, from https://www. ohchr.org/EN/HRBodies/CRC/Pages/DiscussionDays.aspx

UN Committee on the Rights of the Child. (2009). General Comment No. 12 (2009) The right of the child to be heard, July 20, 2009, CRC/C/GC/12. Retrieved October 12, 2020, from https:// digitallibrary.un.org/record/671444? $\mathrm{ln}=$ en

UN Committee on the Rights of the Child. (2010). Concluding observations: Sierra Leone, under article 8 of the Optional Protocol to the Convention on the Rights of the Child on the Involvement of Children in Armed Conflict, Cotber 14, 2010, CRC/C/OPAC/SLE/CO/1. UN. Retrieved November 29, 2020, from http://digitallibrary.un.org/record/692399

UN Committee on the Rights of the Child. (2015). Concluding observations: Colombia, March 6, 2015, CRC/C/COL/CO/4-5. UN. Retrieved November 29, 2020, from http://digitallibrary.un. org/record/789737

UN Committee on the Rights of the Child. (2016a). General Comment No. 20 (2016) on the implementation of the rights of the child during adolescence, December 6, 2016, CRC/C/GC/20. Retrieved October 12, 2020, from https://digitallibrary.un.org/record/855544? $1 \mathrm{n}=\mathrm{en}$

UN Committee on the Rights of the Child. (2016b). Concluding observations: United Kingdom, July 12, 2016, CRC/C/GBR/CO/5. UN. Retrieved November 15, 2020, from http:// digitallibrary.un.org/record/835015

UN Committee on the Rights of the Child. (2017a). Concluding observations: Democratic Republic of the Congo, February 28, 2017, CRC/C/COD/CO/3-5. UN. Retrieved November 29, 2020, from http://digitallibrary.un.org/record/1311372

UN Committee on the Rights of the Child. (2017b). Concluding observations: Central African Republic, March 8, 2017, CRC/C/CAF/CO/2. UN. Retrieved November 14, 2020, from http:// digitallibrary.un.org/record/1311376

UN Committee on the Rights of the Child. (2017c). Concluding observations: United States of America, under article 8 (1) of the Optional Protocol to the Convention on the Rights of the Child on the Involvement of Children in Armed Conflict, July 11, 2017, CRC/C/OPAC/USA/CO/ 3-4. UN. Retrieved November 29, 2020, from http://digitallibrary.un.org/record/1311404

UN Committee on the Rights of the Child. (2017d). Concluding observations: Lebanon, June 22, 2017, CRC/C/LBN/CO/4-5. UN. Retrieved November 6, 2020, from http://digitallibrary.un. org/record/1311380

UN Executive Committee of the UNHCR Programme. (2010). Report of the 61st session of the Executive Committee of the High Commissioner's Programme, A/AC.96/1095. UN. Retrieved November 29, 2020, from http://digitallibrary.un.org/record/697102

UN General Assembly. (2001). Optional protocols to the Convention on the Rights of the Child on the involvement of children in armed conflict and on the sale of children, child prostitution and child pornography, A/RES/54/263. UN. Retrieved November 29, 2020, from http:// digitallibrary.un.org/record/416571

UN High Commissioner for Refugees. (2003). Sexual and gender-based violence against refugees, returnees and internally displaced persons: Guidelines for prevention and response. UN High Commissioner for Refugees. Retrieved November 29, 2020, from http://digitallibrary.un.org/ record $/ 532805$

UNICEF. (2007). Principles and guidelines on children associated with armed forces or armed groups (Paris principles). Retrieved November 29, 2020, from https://www.unicef.org/mali/en/ reports/paris-principles 
Open Access This chapter is licensed under the terms of the Creative Commons Attribution 4.0 International License (http://creativecommons.org/licenses/by/4.0/), which permits use, sharing, adaptation, distribution and reproduction in any medium or format, as long as you give appropriate credit to the original author(s) and the source, provide a link to the Creative Commons license and indicate if changes were made.

The images or other third party material in this chapter are included in the chapter's Creative Commons license, unless indicated otherwise in a credit line to the material. If material is not included in the chapter's Creative Commons license and your intended use is not permitted by statutory regulation or exceeds the permitted use, you will need to obtain permission directly from the copyright holder. 